\title{
Role of Nitric Oxide in Neuromuscular Transmission and Its Effects at Different Frequencies of Nerve Stimulation
}

\author{
*Mohamed M. Emran, *Hemmat M. Kholousy, \\ *Samah El-Attar, **Rasha A El-Deeb \\ *The Physiology Department, Faculty of Medicine, Cairo University \\ **The Physiology Department, Faculty of Medicine, MUST
}

\begin{abstract}
Background: The free radical gas nitric oxide (NO) exhibits diverse vital roles in the human body. It is now recognized as a major messenger molecule. Neural NOsynthase is present in the sarcolemma of type II skeletal muscle fibers. In rats, the NO synthase pathway is present in skeletal muscle, vascular smooth muscle and motor nerve terminal. However, previous studies did not determine whether NO facilitates or impairs neuromuscular transmission in preparations indirectly stimulated at different frequencies. Aim of work: The study aims to examine the effect of NO in rat neuromuscular preparation at different stimulation frequencies and modulation of its effect by hemoglobin (NO scavenger). Methods: 30 rats were used in the experiment and were divided into 2 groups: GpI: rat diaphragms were electrically stimulated by supramaximal stimuli, at low frequency of $0.5 \mathrm{~Hz}$ for $0.5 \mathrm{msec}$, directly and indirectly to induce simple muscle twitch, GpII: rat diaphragms were electrically stimulated by high frequency of $100 \mathrm{~Hz}$, directly and indirectly to induce tetanic contraction. Rat diaphragms were bathed in Krebs solution. To investigate the effect of NO, Larginine was added to the bath in a dose of $4.7 \mathrm{nM} / 50 \mathrm{ml}$ bath. Then bovine Hb (50 $n M / 50 \mathrm{ml}$ bath was added to scavenge NO. A contact time of 3 minutes is allowed for each step and the amplitude of maximal contraction $(\Delta Y)$, contraction time $(\Delta X)$, and $1 / 2$ relaxation time $(1 / 2 R t)$ were measured in $G p I$, while only amplitude of maximal contraction was measured in GPII. Results: NO significantly increased $\Delta Y, \Delta X$ and decreased 1/2 Rt when rat diaphragm preparations were stimulated indirectly at low or high frequencies. In contrast, when rat diaphragm preparations were stimulated directly at either low or high frequencies, NO significantly decreased $\Delta Y, \Delta X$, and increased 1/2 Rt. Bovine Hb completely reversed the NO effects. Conclusion: We can conclude that NO has dual actions, facilitatory and inhibitory, on skeletal muscle contraction using indirect or direct electrical stimulation respectively at both low and high frequencies. Bovine Hb antagonized the effects of NO in all experimental steps, giving an additional proof that the recorded changes were NO mediated.
\end{abstract}

\section{INTRODUCTION}

Until the beginning of 1980 , nitric oxide (NO) was just a toxic molecule of a lengthy list of environmental pollutants such as cigarette smoke. In fact, NO had a very bad reputation of being destroyer of ozone, suspected carcinogen. However, over the last two decades, the picture has been totally changed. NO activity was proved in the brain, 
arteries, immune system, liver, pancreas, uterus, peripheral nerves, lung and almost every system in the human body. The free radical gas nitric oxide (NO) exhibits diverse vital roles in the human body. It is now recognized as a major messenger molecule, participates in the control of vascular tone as an antagonist of the adrenergic regulatory system and it causes smooth muscle relaxation not only at the vascular wall, but also at the gastrointestinal tract. ${ }^{(\mathbf{1})}$

Intracellular NO production is catalyzed by several isoforms of the enzyme nitric oxide synthase(NOS). ${ }^{(2)}$ Because NO is a gaseous free radical and highly diffusible, its formation must be tightly regulated to control its synthesis and specify its signaling. ${ }^{(3)}$

Many studies have shown that the NOS isoforms have a wide tissue distribution. Alternative splicing mechanisms are important in the pattern of NOS expression. ${ }^{(4-5)}$ All major NOS isoforms are expressed in skeletal muscle, suggesting an important role for $\mathrm{NO}$ in muscle physiology. ${ }^{(6)}$

Kobzib et al. ${ }^{(7)}$ proved that the force of contraction in the rat diaphragm has shown to decrease slightly when exposed to NO. In contrast, Morrison et al. ${ }^{(8)}$ proved that the force of contraction in mouse hind limb increased after 15 minute of exposure to NO donors. Furthermore, a recent report demonstrates that the direction of the change in the force in response to NO donors depends significantly on the interval between contractions: more frequent stimulation leads to more increase in the force of contraction in muscle in response to $\mathrm{NO} .{ }^{(9)}$
L-arginine has been given to the training athletes not only as an amino acid but as a donor of NO; that increase NO which enhance the muscular performance through its action on increasing blood flow, glucose uptake and oxygen consumption. ${ }^{(10)}$

Hemoglobin has many functions: it facilitates $\mathrm{O} 2$ transport. It has an important buffer function and it transports NO. Hemoglobin reversibly binds NO which has a very short life time in the blood. This binding sequesters the NO molecule from rapid destruction. ${ }^{(11)}$

Hemoglobin converts unstable free NO to stable compound thus preventing its catalysis in order to deliver it as a potent vasodilator to the blood vessels target when needed. ${ }^{(\mathbf{1 2})}$

Hemoglobin may cross the wall of a large vein, (13) but its diffusion through the membranes of other tissues is negligible. ${ }^{(14)}$ Since hemoglobin only scavenges NO released from tissues, the pre- and postsynaptic neuromuscular effects induced by NO released from skeletal muscle, motor nerve and/or vascular smooth muscle might be reduced or antagonized by previous administration of hemoglobin. ${ }^{(15)}$

The aim of this study is to examine the effect of $\mathrm{NO}$ in rat neuromuscular preparation at different frequencies and modulation of its effect by hemoglobin (NO scavenger)

\section{MATERIALS \& METHODS}

Experimental Protocol:

Thirty Albino Wister male rats, weighing 100-120g were used in the present study. The rat hemidiaphragm 
preparations of these animals were divided into 2 groups; GpI $(n=15)$ the rat diaphragm preparations were electrically stimulated by supramaximal stimuli for $0.5 \mathrm{msec}$ duration and a low frequency of $0.5 \mathrm{~Hz}$, directly and indirectly using a square-wave stimulator, Palmar Electronic England, to induce simple muscle twitch. GpII $(n=15)$ the rat diaphragm preparations were electrically stimulated by high frequency of $100 \mathrm{~Hz}$, directly and indirectly to induce tetanic contraction.

Rat diaphragm preparation

The animals were killed and a rectangular bundles of the diaphragms were dissected and suspended in an organ bath containing oxygenated Kreb's solution at $37{ }^{\circ} \mathrm{C}$ with the central tendon tied to a fixed point and the costal margin tendon tied to an isometric force transducer. ${ }^{(16)}$ The Krebs solution contained (in $\mathrm{mM}$ ) 11.5 glucose, 21.9 bicarbonate, 1.2 phosphate, $\quad 138.5$ sodium, 2.5 calcium, $\quad 1.2$ magnesium, 4.6 potassium, and 125 chloride. The $\mathrm{pH}$ of the solution after $30 \mathrm{~min}$ of bubbling with $95 \% \mathrm{O}_{2}-5 \% \mathrm{CO}_{2}$ was between 7.34 and 7.39. ${ }^{(17)}$

Ten minutes rest after these steps then L-arginine was added to the bath in a dose of $4.7 \mathrm{mM}$. A contact time for 3 minutes was needed before applying direct and indirect electrical stimulation for each preparation and measurements were recorded. After another 10 minutes, bovine $\mathrm{Hb}$, known as NO scavenger, was added to the bath in a dose of $50 \mathrm{nM}$. A contact time for 3 minutes was needed before applying direct and indirect electrical stimulation for the preparations and measurements were recorded.

Contractile measurements:

Maximal twitch force $(\Delta Y)$, contraction time $(\Delta \mathrm{X})$ and half relaxation time $(1 / 2 \mathrm{RT})$ were measured on application of $0.5 \mathrm{~Hz}$ (simple muscle twitch), while the $(\Delta \mathrm{Y})$ was the only parameter measured on application of $100 \mathrm{~Hz}$ (tetanic contraction).

Drugs used:

L-arginine of molecular weight 178 and Bovine Hemoglobin 100g of molecular weight of approximately 64.5 were obtained from MEDICO company.

\section{Statistical Methods}

Values are measured as mean \pm SD. Comparison of data were performed by using the student's ttest.

\section{RESULTS}

1-Effect of indirect supramaximal stimuli of $0.5 \mathrm{msec}$ duration and $0.5 \mathrm{~Hz}$ frequency:

Tables (1),(2), figures (1), (2), and graph (1),(2) show that addition of Larginine to the rat diaphragm preparations in the Kreb's solution bath resulted in a significant increase of $\Delta \mathrm{Y}$ and $\Delta \mathrm{X}$ by $43.1 \%$ and $41.1 \%$ respectively as compared with control values. After adding bovine $\mathrm{Hb}$, $\operatorname{graph}(3), \Delta \mathrm{Y}$ and $\Delta \mathrm{X}$ were significantly reduced by $30.1 \%$ and $35.5 \%$ as compared to values recorded in L-arginine solution bath and returned back to the values recorded in Kreb's solution bath. Table (3), figure (3), and graphs(1,2,3) showed that the $1 / 2 \mathrm{Rt}$ recorded after addition of L-arginine was significantly 
shortened by $32.28 \%$ as compared with values recorded in the control group. After addition of bovine $\mathrm{Hb}$ to the L-arginine bath, 1/2 Rt was significantly increased by $48.06 \%$ compared with the values recorded in L-arginine bath with no significant difference recorded from the values recorded in Kreb's solution bath.

2-Effect of direct supramaximal stimuli of $0.5 \mathrm{msec}$ duration and $0.5 \mathrm{~Hz}$ frequency:

Tables (1),(2), figures (1), (2), and graphs $(4,5)$ showed that on addition of L-arginine to the Kreb's solution bath and applying direct supramaximal stimulation of $0.5 \mathrm{msec}$ duration and $0.5 \mathrm{~Hz}$ frequency, $\Delta \mathrm{Y}$ and $\Delta \mathrm{X}$ showed a significant decline of $24.8 \%$ and $24.2 \%$ respectively, as compared with values recorded in preparations in Kreb's solution bath. The addition of bovine $\mathrm{Hb}$, graph (6), to the bath antagonized completely the effect of L-arginine with improvement of $\Delta \mathrm{Y}$ and $\Delta \mathrm{X}$ values to be significantly higher than values recorded after adding L-arginine with insignificant difference from values recorded in Kreb's solution bath. As regard the $1 / 2 \mathrm{Rt}$, Table (3), figure (3), and graphs $(4,5,6)$ showed that it was significantly increased by $70.9 \%$ on adding L-arginine to the Kreb's solution bath. On the other hand, addition of bovine $\mathrm{Hb}$ resulted in a significant reduction of the values recorded for $1 / 2 \mathrm{Rt}$ in the L-arginine bath by $30.03 \%$. These values were still higher than the values recorded in the Kreb's solution bath, but this difference was insignificant.
3-Effect of indirect high frequency stimulation $(100 \mathrm{~Hz})$ :

Table (4) figure (4), and graphs $(7,8)$ show that the addition of Larginine to the Kreb's solution bath caused a significant increase of $20.7 \%$ in $\Delta \mathrm{Y}$ compared with mean values recorded in the Kreb's solution bath. Following the addition of bovine $\mathrm{Hb}$ to the bath containing L-arginine, graph (9), $\Delta \mathrm{Y}$ was significantly decreased by $17.97 \%$ compared to values recorded in the presence of Larginine alone. This value was insignificant as compared with values recorded in the Kreb's solution bath.

4-Effect of direct high frequency stimulation $(100 \mathrm{~Hz})$ :

Table (4) and figure (4), and graphs $(10,11)$ showed that $\Delta Y$ was significantly decreased by $9.82 \%$ on addition of L-arginine to the Kreb's solution bath. Moreover, when $\Delta \mathrm{Y}$ was recorded in the presence of bovine $\mathrm{Hb}$ added to the L-arginine bath, graph (12), it was significantly increased by $10.8 \%$ in relation to its mean values in the presence of Larginine alone. This value showed insignificant difference when compared to that recorded in Kreb's solution bath.

Addition of L-arginine to Kreb's solution bath had an opposite effect on $\Delta \mathrm{Y}$ parameter while applying direct or indirect electrical stimulation to the rat diaphragm. In case of direct stimulation, L-arginine caused a significant decrease in $\Delta \mathrm{Y}$, while it caused a significant increase in $\Delta Y$ in case of applying indirect electrical stimulation. 
Table (1): Changes in $\Delta \mathrm{Y}(\mathrm{g} / \mathrm{cm} 2)$ at low frequency of $0.5 \mathrm{~Hz}$ in $\mathrm{Gpl}$, when direct and indirect electrical stimulation were applied.

\begin{tabular}{|c|c|c|c|c|c|c|}
\hline \multicolumn{7}{|c|}{ Changes in $\Delta y(\mathrm{~g} / \mathrm{cm} 2)$ at low frequency of $0.5 \mathrm{~Hz}$ in $\mathrm{Gp1}$} \\
\hline & \multicolumn{3}{|c|}{ Indirect stimulation } & \multicolumn{3}{|c|}{ Direct stimulation } \\
\hline & $\begin{array}{l}\text { Kreb's } \\
\text { solution }\end{array}$ & $\begin{array}{l}\text { Kreb's } \\
\text { solution }+ \\
\text { L-argnine }\end{array}$ & $\begin{array}{l}\mathrm{L}- \\
\text { argnine/ } \\
\text { Bovine } \mathrm{Hb}\end{array}$ & $\begin{array}{l}\text { Kreb's } \\
\text { solution }\end{array}$ & $\begin{array}{l}\text { Kreb's + } \\
\text { L- argnine }\end{array}$ & $\begin{array}{l}\mathrm{L}- \\
\text { argnine/ } \\
\text { Bovine } \\
\mathrm{Hb}\end{array}$ \\
\hline Mean & 5.85 & 8.37 & 5.85 & 10.29 & 7.73 & 9.52 \\
\hline $\mathrm{SD} \pm$ & 1.75 & 1.95 & 1.75 & 1.77 & 1.57 & 2.36 \\
\hline $\begin{array}{l}\% \text { of } \\
\text { changes }\end{array}$ & & $+43.1 \%$ & $-30.1 \%$ & & $-24.8 \%$ & $+23.1 \%$ \\
\hline $\mathrm{P}$ & & $<0.05^{*}$ & $\begin{array}{l}<0.05 * * \\
>0.05 \#\end{array}$ & & $<0.05^{*}$ & $\begin{array}{l}<0.05 * * \\
>0.05 \#\end{array}$ \\
\hline
\end{tabular}

* Significant value compared to its value in the Kreb's solution bath.

** Significant value compared to its value in the presence of $\mathrm{L}$-argnine/Bovine $\mathrm{Hb}$ in the bath. \# Insignificant value compared to its value in Kreb's solution.

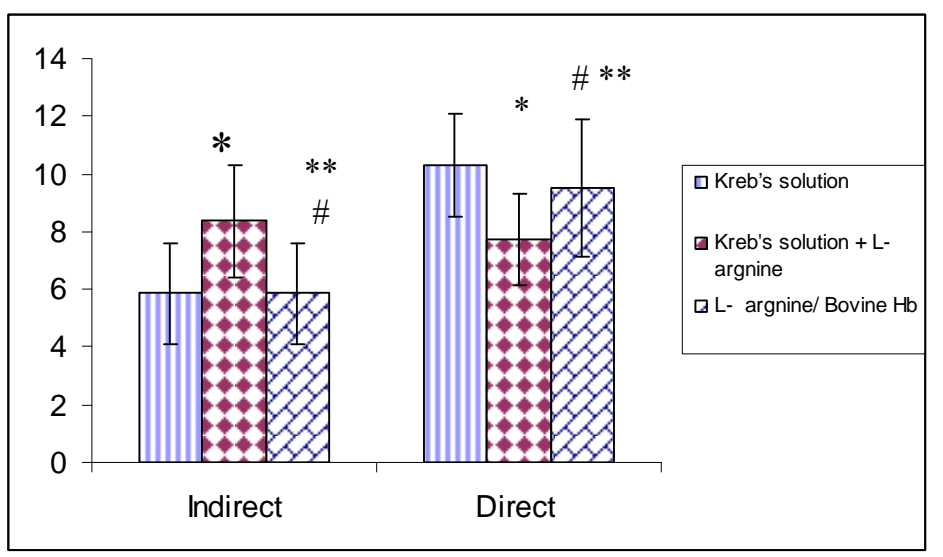

Figure (1): Changes in $\Delta Y(\mathrm{~g} / \mathrm{cm} 2)$ at low frequency of $0.5 \mathrm{~Hz}$ in $\mathrm{Gpl}$, when direct and indirect electrical stimulation were applied. 
Table (2): Changes in $\Delta X$ (msec) at low frequency of $0.5 \mathrm{~Hz}$ in $\mathrm{Gpl}$, when direct and indirect electrical stimulation were applied.

\begin{tabular}{|l|l|l|l|l|l|l|}
\hline \multicolumn{6}{|c|}{ Changes in $\boldsymbol{\Delta} \mathbf{X}$ (msec) at low frequency 0.5Hz of electrical stimulation (Gp1) } \\
\hline & Indirect stimulation & \multicolumn{4}{l|}{ Direct stimulation } \\
\cline { 2 - 7 } & $\begin{array}{l}\text { Kreb's } \\
\text { solution }\end{array}$ & $\begin{array}{l}\text { Kreb's } \\
\text { solution + L- } \\
\text { argnine }\end{array}$ & $\begin{array}{l}\text { L- argnine/ } \\
\text { Bovine Hb }\end{array}$ & $\begin{array}{l}\text { Kreb's } \\
\text { solution }\end{array}$ & $\begin{array}{l}\text { Kreb's + } \\
\text { L- argnine }\end{array}$ & $\begin{array}{l}\text { L- argnine/ } \\
\text { Bovine Hb }\end{array}$ \\
\hline Mean & 0.0496 & 0.0701 & 0.0452 & 0.0491 & 0.0372 & 0.0482 \\
\hline $\mathrm{SD} \pm$ & 0.0086 & 0.0092 & 0.0091 & 0.0081 & 0.007 & 0.0089 \\
\hline $\begin{array}{l}\% \text { of } \\
\text { changes }\end{array}$ & & $+41.1 \%$ & $-35.5 \%$ & & $-24.2 \%$ & $+29.5 \%$ \\
\hline $\mathrm{P}$ & & $<0.05^{*}$ & $\begin{array}{l}<0 / 05^{* *} \\
>0.05 \#\end{array}$ & & $<0.05^{*}$ & $\begin{array}{l}<0 / 05^{* *} \\
>0.05 \#\end{array}$ \\
\hline
\end{tabular}

* Significant value compared to its value in the Kreb's solution bath.

** Significant value compared to its value in the presence of L-argnine/Bovine Hb in the bath.

\# Insignificant value compared to its value in Kreb's solution.

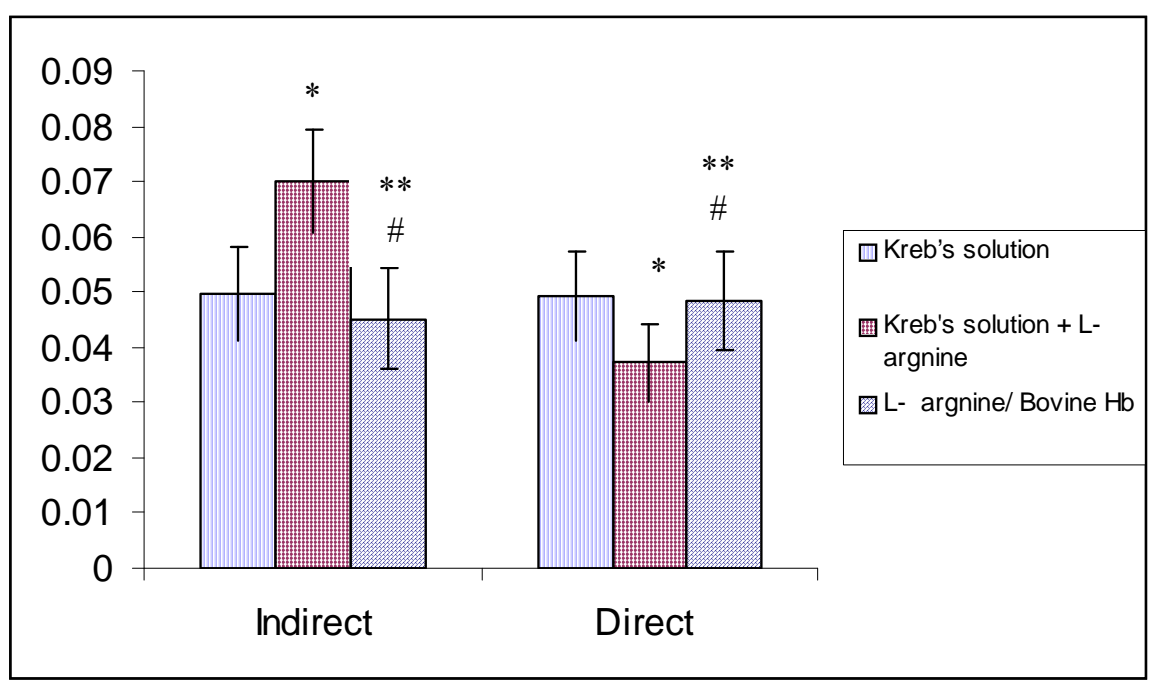

Figure (2) Changes in $\Delta X$ (msec) at low frequency of $0.5 \mathrm{~Hz}$ in $\mathrm{Gpl}$, when direct and indirect electrical stimulation were applied. 
Table (3): Changes in $1 / 2 \mathrm{Rt}$ (msec) at low frequency of $0.5 \mathrm{~Hz}$ in $\mathrm{Gpl}$, when direct and indirect electrical stimulation were applied.

\begin{tabular}{|l|l|l|l|l|l|l|}
\hline \multicolumn{7}{|c|}{ Changes in $1 / 2$ Rt (msec) at low frequency $0.5 \mathrm{~Hz}$ of electrical stimulation (Gp1) } \\
\hline & \begin{tabular}{l} 
Indirect stimulation \\
\cline { 2 - 7 }
\end{tabular} & $\begin{array}{l}\text { Kreb's } \\
\text { solution } \\
\text { Solution }+ \\
\text { L- argnine }\end{array}$ & $\begin{array}{l}\text { L- argnine/ } \\
\text { Bovine Hb }\end{array}$ & $\begin{array}{l}\text { Kreb's } \\
\text { solution }\end{array}$ & $\begin{array}{l}\text { Kreb's + } \\
\text { L- argnine }\end{array}$ & $\begin{array}{l}\text { L- argnine/ } \\
\text { Bovine } \\
\text { Hb }\end{array}$ \\
\hline Mean & 0.0754 & 0.05106 & 0.0756 & 0.0334 & 0.05714 & 0.0399 \\
\hline SD \pm & 0.0154 & 0.0122 & 0.0062 & 0.0072 & 0.00692 & 0.0052 \\
\hline $\begin{array}{l}\% \text { of } \\
\text { changes }\end{array}$ & & $-32.28 \%$ & $+48.06 \%$ & & $+70.9 \%$ & $-30.03 \%$ \\
\hline P & & $<0.05^{*}$ & $\begin{array}{l}<0 / 05^{* *} \\
>0.05 \#\end{array}$ & & $<0.05^{*}$ & $\begin{array}{l}<0.05^{* *} \\
>0.05 \#\end{array}$ \\
\hline
\end{tabular}

* Significant value compared to its value in the Kreb's solution bath.

** Significant value compared to its value in the presence of L-argnine/Bovine Hb in the bath.

\# Insignificant value compared to its value in Kreb's solution.

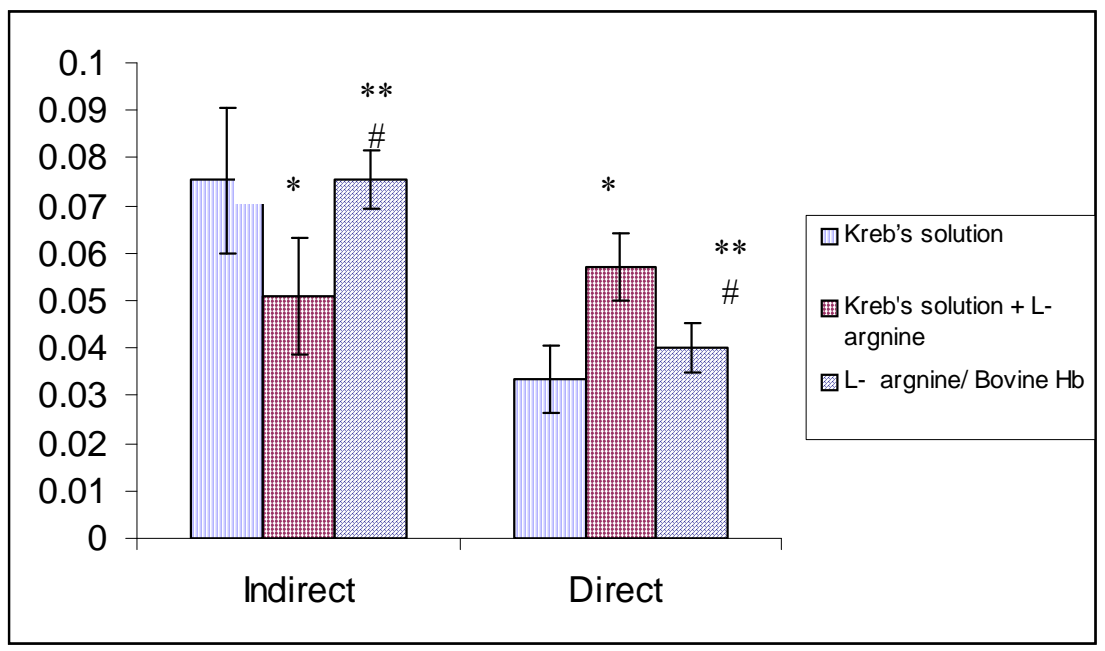

Figure (3) Changes in $1 / 2$ Rt (msec) at low frequency of $0.5 \mathrm{~Hz}$ in $\mathrm{Gpl}$, when direct and indirect electrical stimulation were applied. 
Table (4): Changes in $\Delta Y\left(\mathrm{~g} / \mathrm{cm}^{2}\right)$ at high frequency of $100 \mathrm{~Hz}$ in $\mathrm{Gp2}$, while indirect and direct electrical stimulation were applied.

Changes in $\Delta \mathrm{Y}(\mathrm{g} / \mathrm{cm} 2)$ at high frequency $100 \mathrm{~Hz}$ of electrical stimulation $(\mathrm{Gp} 2)$

\begin{tabular}{|c|c|c|c|c|c|c|}
\hline & \multicolumn{3}{|c|}{ Indirect stimulation } & \multicolumn{3}{|c|}{ Direct stimulation } \\
\hline & $\begin{array}{l}\text { Kreb's } \\
\text { solution }\end{array}$ & $\begin{array}{l}\text { Kreb's } \\
\text { solution + } \\
\text { L- argnine }\end{array}$ & $\begin{array}{l}\text { L- argnine/ } \\
\text { Bovine } \mathrm{Hb}\end{array}$ & $\begin{array}{l}\text { Kreb's } \\
\text { solution }\end{array}$ & $\begin{array}{l}\text { Kreb's + } \\
\text { L- argnine }\end{array}$ & $\begin{array}{l}\text { L- argnine/ } \\
\text { Bovine } \\
\mathrm{Hb}\end{array}$ \\
\hline Mean & 14.650 & 17.693 & 14.513 & 25.75 & 23.22 & 25.75 \\
\hline $\mathrm{SD} \pm$ & 2.47 & 2.311 & 2.472 & 1.746 & 4.361 & 1.708 \\
\hline $\begin{array}{l}\% \text { of } \\
\text { changes }\end{array}$ & & $+20.7 \%$ & $-17.97 \%$ & & $-9.82 \%$ & $+10.8 \%$ \\
\hline $\mathrm{P}$ & & $<0.05^{*}$ & $\begin{array}{l}<0.05^{* *} \\
>0.05 \#\end{array}$ & & $<0.05^{*}$ & $\begin{array}{l}<0.05 * * \\
>0.05 \#\end{array}$ \\
\hline
\end{tabular}

* Significant value compared to its value in the Kreb's solution bath.

** Significant value compared to its value in the presence of L-argnine/Bovine Hb in the bath.

\# Insignificant value compared to its value in Kreb's solution

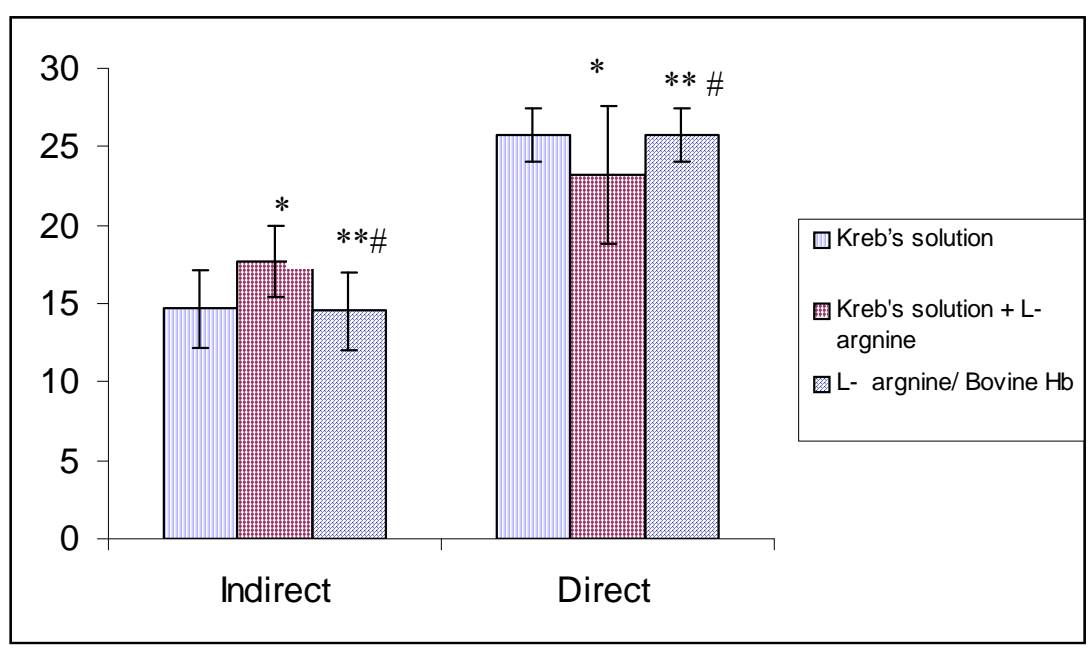

Figure (4): Changes in $\Delta Y(\mathrm{~g} / \mathrm{cm} 2)$ at high frequency of $100 \mathrm{~Hz}$ in $\mathrm{Gp2}$, while indirect and direct electrical stimulation were applied. 


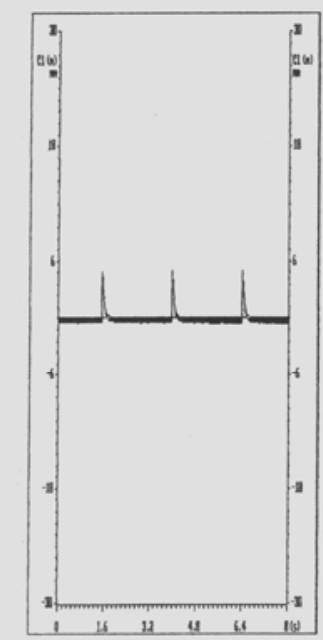

Graph (1): shows indirect stimulation of rat diaphragm preparation in Kreb's solution at low frequency 0.5 $1 / 2 \mathbf{R t}=0.0754$

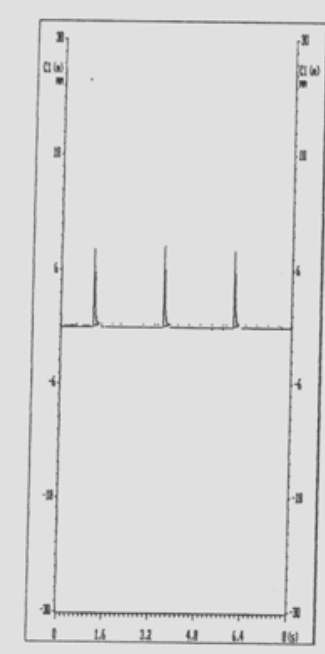

Graph (2): shows indirect electrical stimulation of rat diaphragm preparation in the presence of $\mathrm{L}=$ =argnine in the bath at low frequency $0.5 \mathrm{~Hz}$ (GpI), where the mean of $6, \Delta X=0.02170,1 / 2$ Rt $=0.02378$
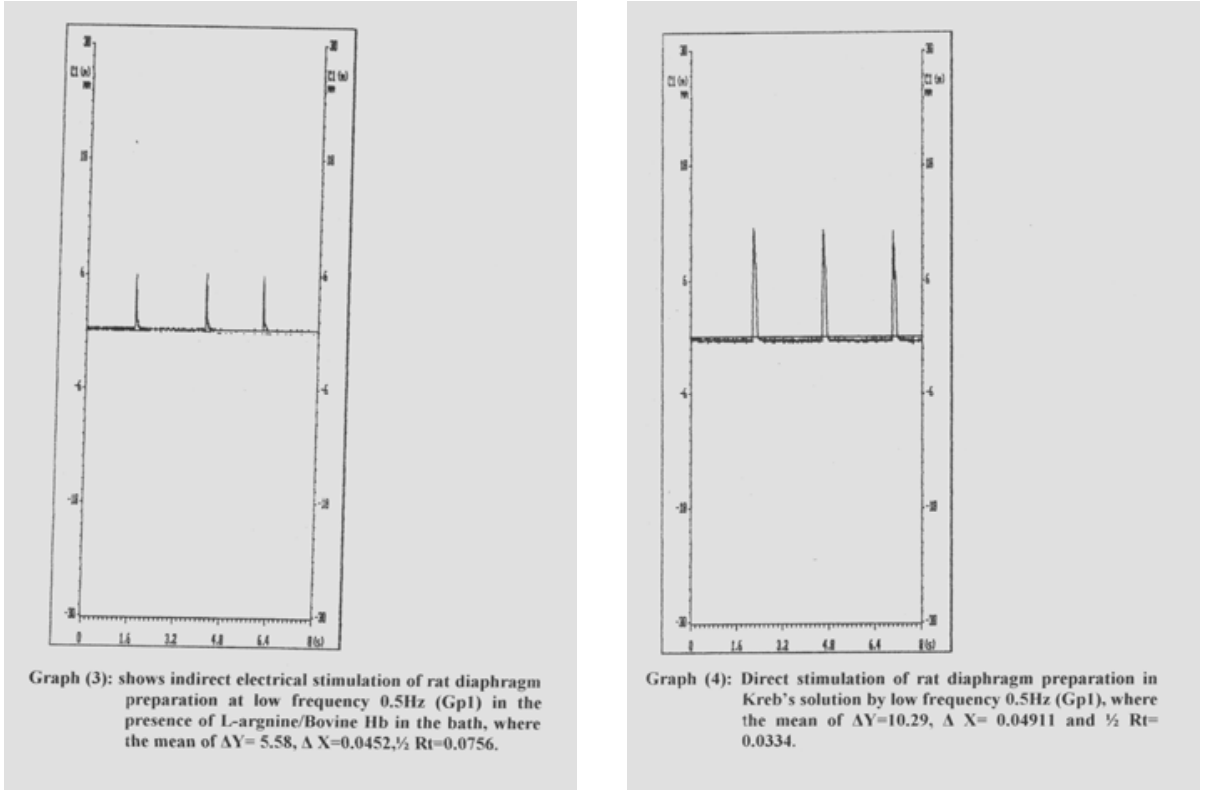

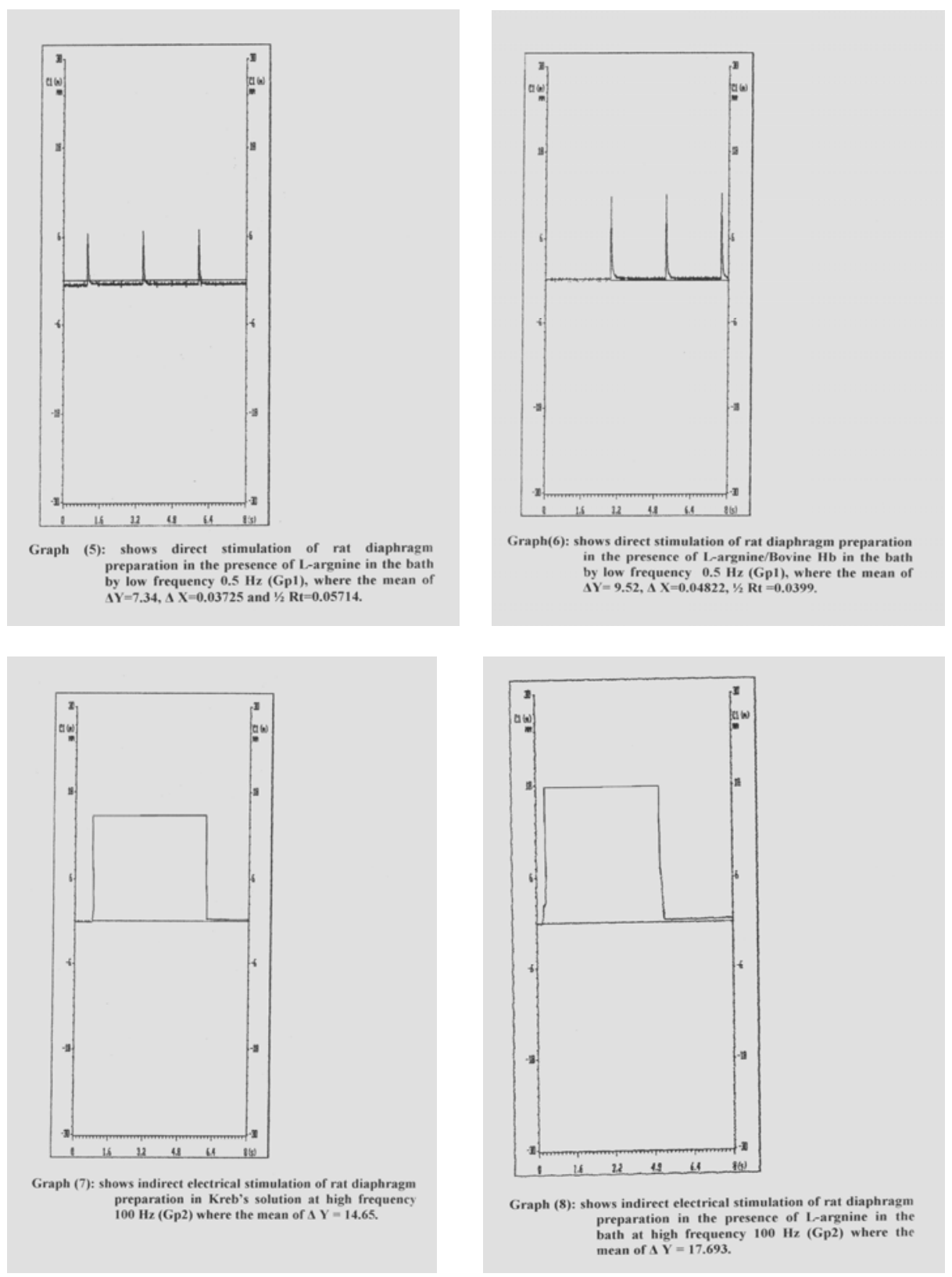

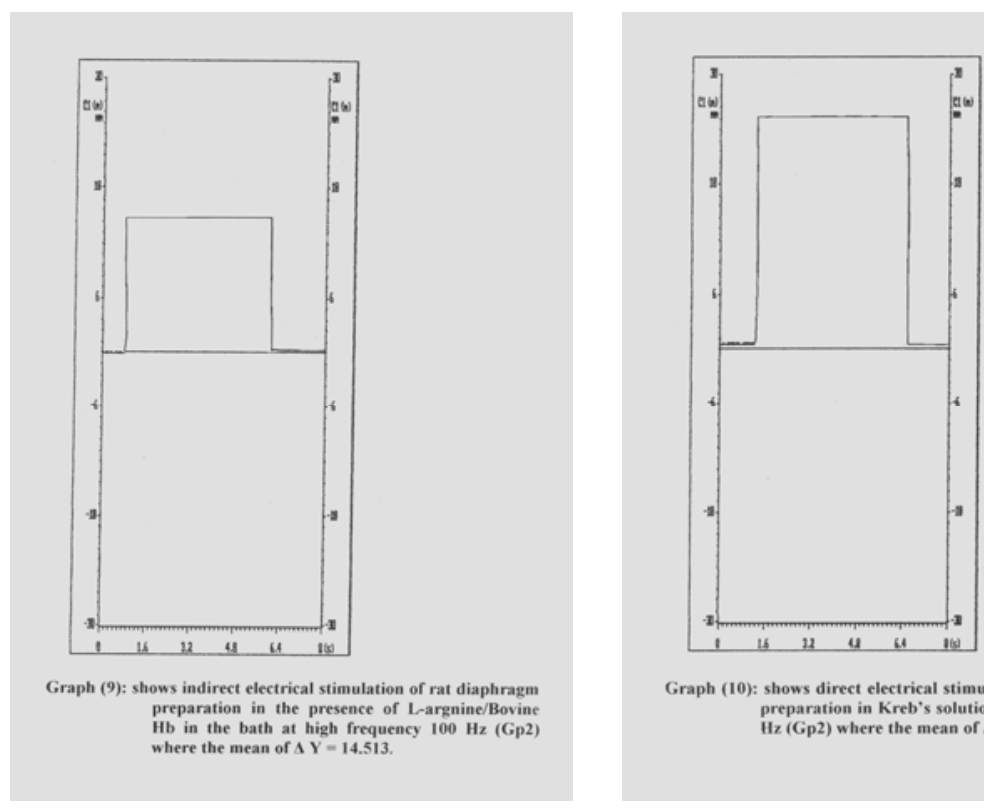

Graph (10): shows direct electrical stimulation of rat diaphragm preparation in Kreb's solution at high frequency 100 Hz (Gp2) where the mean of $\Delta Y=25.75$.
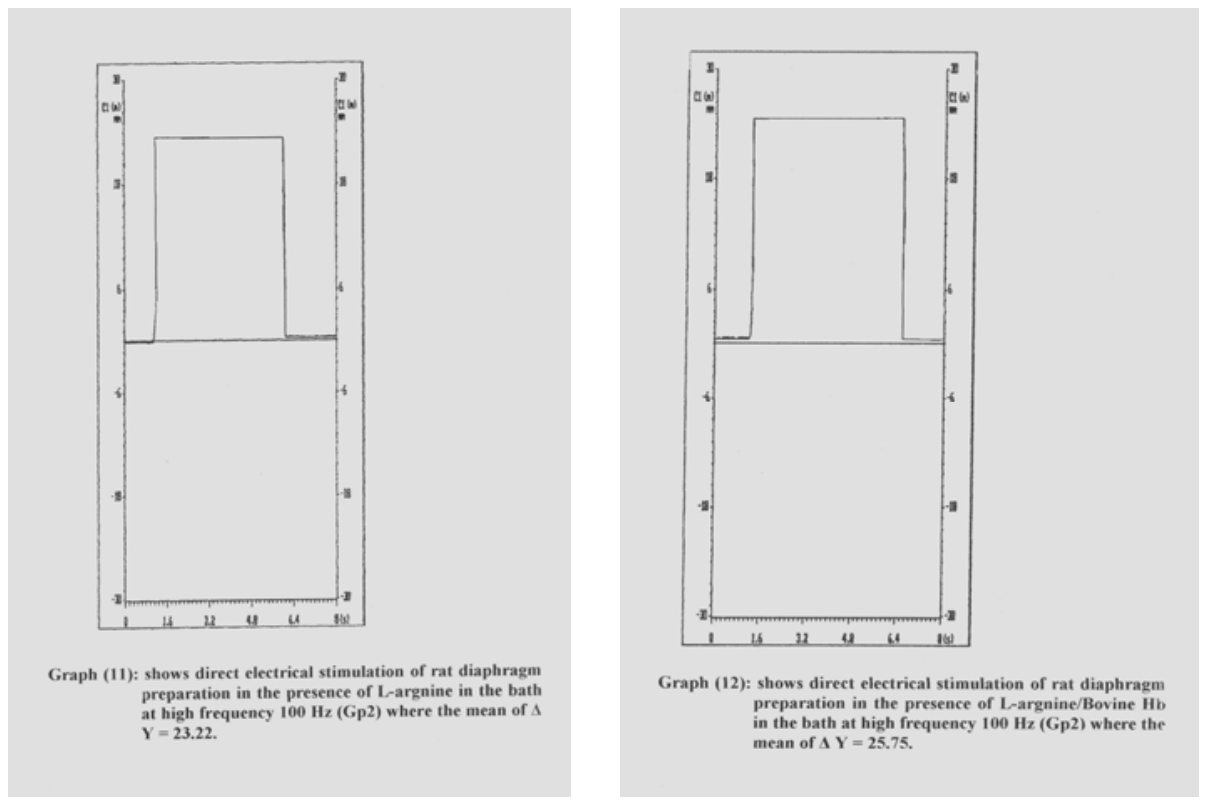


\section{DISCUSSION}

Thomas and Robitaille have evident that NO is a potent neuromodulator in the central and peripheral nervous system and a modulator of synaptic transmission at the neuromuscular junction. ${ }^{(18)}$ The present study was designed to focus the light on the effect of $\mathrm{NO}$ on the contractility of rat diaphragm using direct and indirect stimulation at low $(0.5 \mathrm{~Hz})$ and high frequency $(100 \mathrm{~Hz})$. Hemoglobin is known to bind avidly and to nullify rapidly the effects of NO. Although hemoglobin does not enter the cells and it scavenges NO extracellularly, it may scavenge NO generated intracellularly by creating a diffusion gradient for NO out of the cell. Thus it was used as a further evidence that the observed responses were NO mediated. ${ }^{(19)}$

Results of the present work showed that the addition of L-arginine $(4.7-9.4 \mathrm{mM})$ to the rat diaphragm preparations was followed by a significant increase in the amplitude of the muscular contraction, $\Delta \mathrm{Y}$, and contraction time, $\Delta \mathrm{X}$, with a significant decrease in the half relaxation time, $1 / 2 \mathrm{Rt}$, in the indirectly stimulated preparations at $0.5 \mathrm{~Hz}$ as compared with values recorded in the Kreb's solution bath.

These results were in agreement with those reported by Ambiel and Alves-Do-Prado, ${ }^{(20)}$ who found that L-arginine produced a dose dependent increase of amplitude of muscle contraction (AMC) in rat neuromuscular preparations when stimulated indirectly at $0.2 \mathrm{~Hz}$. However, Queiroz and Alves-DoPrado, ${ }^{(21)}$ reported that the amplitude of muscle contraction was stable when the rat diaphragm was indirectly stimulated at $0.2 \mathrm{~Hz}$ frequency and a progressive increase in AMC was observed at 5 and $50 \mathrm{~Hz}$.

Many studies tried to explain the NO mediated improvement in muscle contraction, and whether it was related to a pre- or postsynaptic effect. (22)

NO acting at presynaptic level might increase acetylcholine release from motor nerve terminals. It is known that the release of acetylcholine from motor nerve terminals could be modulated by endogenous agents. NO might possibly represent one of these modulating factors. ${ }^{(21)} \mathrm{UC}$ et al., (23) suggested that activation of a soluble guanylate cyclase leading to the promotion of cGMP seems to be the main mechanism by which NO modulates transmitter release during application of low frequency electrical stimulation. In addition, there was an evidence that NO facilitated N-type $\mathrm{Ca}^{2+}$ channel activation via a cGMPPKC pathway. These channels are clustered at active zones of neuromuscular junctions, regulating transmitter release. ${ }^{(\mathbf{2 3})}$

In this regard, it is particularly interesting that neuronal nitric oxide synthase (nNOS) and cGMPdependent protein kinase, which are the primary effectors of $\mathrm{NO}$, were found to be concentrated at the neuromuscular end plate. ${ }^{(24)}$ Moreover, Wang et al. ${ }^{(25)}$ noticed that cGMP-dependent kinase phosphorylates the nicotinic acetylcholine receptor subunits in cultured myocytes. 
In an attempt to clarify whether the improved muscle contraction that followed the addition of L-arginine was due to its effect at a pre-or postsynaptic level, we studied its effect on directly stimulated rat diaphragm preparations.

In the present work, following the addition of L-arginine (4.7$9.4 \mathrm{mM}$ ) in vitro to rat diaphragm preparation stimulated directly at low frequency of $0.5 \mathrm{~Hz}$, the amplitude of maximum contraction and the contraction time of the simple muscle twitch were significantly reduced as compared with values recorded in the Kreb's solution bath. In addition, the relaxation time (1/2Rt) was significantly increased. These results were in accordance with those reported by Queiroz and Alves-DoPrado, ${ }^{(21)}$ who revealed that the NO precursor L-arginine (4.7-9.4mM) reduced the AMC of the directly stimulated skeletal muscle using a frequency of $0.2 \mathrm{~Hz}$. It was also shown by Kozik et al. ${ }^{(7)}$ that endogenous NO synthesis inhibits muscle contractility, especially in response to low frequency stimulation.

Because of the limited magnitude of cGMP-mediated changes in skeletal muscle in contrast to smooth muscle, NO might act directly on modulating regulatory proteins via redox effect. Thiol groups of the $\mathrm{Ca}^{2+}$ release channels of sarcoplasmic reticulum (SR) are likely for such interaction. ${ }^{\text {(26) }}$ Reactive thiols present on the myosin head are another potential targets. This modulation would reduce maximal force generation. Thus the effect of NO appeared to be mediated through cGMP-dependent and cGMP independent mechanisms involving in excitation contraction coupling and sarcoplasmic reticulum Ca flux. ${ }^{(27)}$ It has been shown that thiol groups present on the RyR (ryanodine receptor) $\mathrm{Ca}^{2+}$ release channel play a role in the regulation of its open probability. ${ }^{(28)} \mathrm{NO}$ can react with thiol groups via either $S$-nitrosylation or by influencing disulphide formation. ${ }^{(29)}$ Therefore, the RyR $\mathrm{Ca}^{2+}$ release channel is a possible target for NO. These data do not definitely indicate that the RyR $\mathrm{Ca}^{2+}$-release channel was the primary target for NO; because other proteins involved in excitationcontraction coupling contain thiol groups as well. Decreased open probability of the channel after exposure to NO may be the result of the inhibitory effect of $\mathrm{NO}$ on intersubunit cross-linking of thiol groups on the RyR channel, thereby preventing oxidant-induced activation of the channel. ${ }^{(30)}$ In contrast, at high concentration, NO increases RyR Ca ${ }^{2+}$ release channel open probability ${ }^{(30 \& 31)}$ indicating differential concentrationdependent effects of NO.

Both activation and inhibition of the RyR have been reported, suggesting that $\mathrm{NO}$ and related molecules can interact with more than one regulatory site. ${ }^{(30 \& 32 \& 33 \& 34)}$ In particular, Meszaros et al. ${ }^{(33)}$ demonstrated that a skeletal NOS can inhibit RyR activity. Another possible explanation of reduced AMC by NO was suggested by Perkins et al., ${ }^{(35)}$ who reported that treatment of muscles with NO donors can inhibit actomyosin ATPase activity (actinmyosin cross-bridge cycling) and thereby reduce skeletal muscle force. However, it is difficult to imagine 
how physiological concentrations of NO might achieve this effect.

Although there was no direct evidence that $\mathrm{NO}$ affected $\mathrm{Ca}^{2+}$ binding to troponin $\mathrm{C}(\mathrm{TnC})$ which contains cysteine residues known to be susceptible to reactive oxidants, a change was likely to occur when NO modified these residues. Biochemical studies showed that disulfide cross-linking of these residues decreased $\mathrm{Ca}^{2+}$ sensitivity of TnC. ${ }^{(36)}$ In fact, after disulfide cross linking of cysteine residues, the troponin complex was no longer able to regulate actomysin ATPase activity in a $\mathrm{Ca}^{2+}$-dependent manner.

In addition, skeletal muscle nNOS was reported to play a role in the regulation of a number of cellular processes such as contractile activity, glucose uptake and blood flow distribution, but the importance of sarcolemmal targeting of nNOS for these regulatory functions is largely unknown.

Finally, it has been established that endogenous NO synthesis in a variety of cells, including skeletal muscles, attenuates mitochondrial respiration by reversibly inhibiting mitochondrial enzymes such as cytochrome-c oxidase. ${ }^{(37)}$

In the present work, and following indirect electrical stimulation of the rat diaphragm at $100 \mathrm{~Hz}$, tetanic contraction of the muscle developed and recorded. The amplitude of maximum contraction was observed to be significantly improved after the addition of Larginine to the rat diaphragm preparation as compared with values recorded in the Kreb's solution bath.
These results were in agreement with Schuman and Madison, (38) who suggested that, during high frequency stimulation, endogenous and exogenous NO increased basal acetylcholine release from the central and peripheral cholinergic neurons. It had been proposed that acetylcholine, in addition to acting on subsynaptic membranes, also acts on prejunctional cholinoceptors to change the acetylcholine mobilization process and thus to control the neurotransmitter output during tetanic stimulation. In addition, Queiroz and Alves-Do-Prado, (21), suggested that the increase in the amplitude of muscle contraction produced at different frequencies, depends on ability of NO to scavenge superoxide anions.

In contrast to its effect on the indirectly stimulated preparation, Larginine reduced the amplitude of maximal tetanic contraction when the high frequency stimulation was applied directly as compared with values recorded in Kreb's solution bath.

Similar results were reported by Morrison et al. ${ }^{(\mathbf{8})}$ who demonstrated that the NO donor increased the responses evoked by a brief trails of stimuli and they suggested that NO modulates a frequency dependent $\mathrm{Ca}^{2+}$ mechanism. Lawler and $\mathrm{Hu},{ }^{(39)}$ suggested that at the frog neuromuscular junction, NO acts via cGMP-independent mechanism, and that potential targets of NO might be the sarcoplasmic $\mathrm{Ca}^{2+} /$ ATPase pump that is known to be S-nitrosylated by NO.

In the present work, in order to confirm that the obtained results were 
NO mediated, bovine hemoglobin $(50 \mathrm{nM})$ was added to the bath $(50 \mathrm{ml})$ containing L-arginine. Rat diaphragm when directly stimulated at frequencies of 0.5 and $100 \mathrm{~Hz}$ showed an increase in $\Delta \mathrm{Y}$ of simple muscle twitch and of tetanic contraction. While when indirectly stimulated $\Delta \mathrm{Y}$ of simple muscle twitch and of tetanic contraction were decreased significantly as compared with Larginine treated preparations, In addition, there was not any significant change in the mean value of $\Delta \mathrm{Y}$ at either low or high frequency when any of the direct and indirect stimulation were applied, compared with their values in Kreb's solution bath. Therefore, depending on these data, we can accept that the observed results were, to a great extent, due to NO enriched medium.

\section{Conclusion:}

Finally, we can conclude that NO formed from L-arginine through the NO synthase pathway present in the sarcolemma of type II fibers of rat skeletal muscle in which contractility is depressed by NO donors when the phrenic nerve diaphragm preparations are directly stimulated. In contrast, NO increases the amplitude of muscular contraction of indirectly stimulated preparations at either low or high frequency. Therefore, we can propose that NO increases the amplitude of muscular contraction when it interacts at presynaptic level. The presynaptic action of NO reduces the effect produced by its postsynaptic action. Whether its postsynaptic action was primarily at the motor end plate or at the intracellular level, further investigation while blocking nicotinic receptors at neuromuscular junction is recommended.

On the basis of the above observation NO has dual action; facilitatory and inhibitory in pre- and postsynaptic respectively and that hemoglobin act as scavenger for NO which may antagonize or reduce its effect.

\section{REFERENCES}

1- Culotta E. and Koshland D.E. NO news is good news. Science. 1992; 258:1865-1892.

2- Stojanovic R., Toobrovic Z., Neric Z., Vuckovic S.,CerovacCosic N. , Prostran M. Ng-nitroL-arginine methyl ester induced potentiation of the effect of aminophilline on rat diaphragm: the role of extracellular calcium. J Pharmacol Sci. 2004; 96(4): 193198.

3- Bredt DS. Nitric oxide signaling specificity - the heart of the problem. J Cell Sci. 2003;116:915

4- Förstermann U, Schmidt HH, Pollock JS, et al. Isoforms of nitric oxide synthase. Characterization and purification from different cell types. Biochem Pharmacol. 1991;42:1849-1857

5- Michel T, Feron O. Nitric oxide synthases: Which, where, how and why? J Clin Invest. 1997;100:2146-2152.

6- Mungrue N, Bredt DS, Stewart DJ, Husain M. From molecules to mammals: What's NOS got to do with it? Acta Physiol Scand. 2003;179:123-135 
7- Kobzik L, Reid MB, Bredt DS, Stamler JS. Nitric oxide in skeletal muscle. Nature.1994; 372:546-548.

8- Morrison RJ, Miller CC, Reid MB. Nitric oxide effects on shortening velocity and power production in the rat diaphragm. $\mathrm{J}$ Appl Physiol. 1996; 80:10651069.

9- Andrade FH, Reid MB, Allen DG, Westeblade $H$. Effect of nitric oxide on single skeletal muscle fibres from mouse. The $\mathrm{J}$ of Physiol. 1998; 509(2): 577586.

10- Chao DS, Gorospe RM, Brenman JA, Rafael MF, Frocher EP, Hoffman J. Selective loss of sarcolemmal nitric oxide synthase in Becker muscular dystrophy. J Exp Med. 1996; 184: 609-618.

11- Clanton TL. Invited editorial introduction to nitric oxide and the respiratory musculature: a short history of nitric oxide in skeletal muscle function. Comp Biochem Physiol. 1998; 1119: 165-176.

12- Schultz RM, Liebman MV. Proteins II: structure-function relationship in protein families. In text book of biochemistry with clinical application, 2002;p. 368412. Chapter 9, $5^{\text {th }}$ edition by Thomas M. Devlin (Ed): WileyLiss.

13- Skopp G, Potsch L, Lutz R, Ganssmann B \& Mattern R. Hemoglobin diffusion across a venous wall: an experimental study. American Journal of Forensic Medicine and Pathology. 1998; 19: 372-376.
14- Vaughn MW, Huang KT, Kuo L \& Liano JC. Erythrocytes possess an intrinsic barrier to nitric oxide consumption. Journal of Biological Chemistry. 2000; 275: 2342-2348.

15- Hakim TS, Sugimori K, Camporesi EM \& Anderson G. Half-life of nitric oxide in aqueous solutions with and without haemoglobin. Physiological Measurement, 1996; 17: 267-277.

16- Matuszczak Y, Vhres, Allamedin H, Cubier M, Desmonts JM, Durui IB. Alteration in diaphragmatic function induced by acute necrotizing pancreatitis in a rat model. Am J Resp Crit Care Med.1999: 160 (5):1623-1628.

17- Raj K. Goyal and Xue D. He. Evidence for NO redox form of nitric oxide as nitrergic inhibitory neurotransmitter in gut . Am J Physiol Gastrointest Liver Physiol. 1998; 275(5): G1185G1192.

18- Thomas S, Robitaille R. Differential frequency- dependent regulation of transmitter release by endogenous nitric oxide at amphibian neuromuscular synapses.Nature.2001; 374: 262266.

19- Gouid SA, Moss GS. Clinical development of human polymerized hemoglobin as a blood substitute. World J Surg.1996; 275: G1185-1192.

20- Ambiel CR, Alves-Do-Prado W. Neuromuscular facilitation and blockade induced by L-arginine and nitric oxide in the rat isolated diaphragm.

General 
Pharmacology. 1997; 28: 789794.

21- Queiroz RN, Alves-Do_Prado. Effect of L-arginine on the diaphragm muscle twitches elicited at different frequencyies of nerve stimulation. Braz J Med Res. 2001 June; 34(6): 825-828.

22- Cruciol-Souza JM, Alves-DoPrado W. Atropine and ODQ antagonize titanic fade induced by L-arginine in cats. Braz J Med and Biol Research. 1999; 32:1277-1283.

23- Uc A, Oh ST, Murray JA, Clark E, Conklin JL. Biphasic relaxation of the oesophageal sphincter: role of NO, VIP and CGRP. American J Physiol.1999; 277: G548-554.

24- Loscalzo J. What we know and don't know about L-arginine and NO. Circulation.2000; 101:21262129.

25- Wang T, Xie Z, Lue B. Nitric oxide mediates activitydependent synaptic suppression at developing neuromuscular synapses. Nature.1995; 374:262266.

26- Koh SD, Camphell JD, Cart A, Sanders KM. Nitric oxide activates channels in canine colonic smooth muscle. $\mathrm{J}$ of Physiol. 1995; 489: 735-743.

27- Olgart C, Wiklund NP, Gustafsson LE. Blockade of nitric oxide-evoked contractions by an inhibitor of guanylyl cyclase. Neuro report.1997; (8): 3355-3358.

28- Abramson, JJ, and Salama G. Critical sulfhydryls regulate calcium release from sarcoplasmic reticulum. J
Bioenerg Biomembr. 1989: 21: 283-294.

29- Stamler, JS. Redox signaling: nitrosylation and related target interactions of nitric oxide. Cell. 1994:78: 931-936.

30- Aghdasi, B, Reid MB, and Hamilton SL. Nitric oxide protects the skeletal muscle $\mathrm{Ca}^{2+}$ release channel from oxidationinduced activation. J Biol Chem. 1997; 272: 25462-25467.

31- Stoyanovsky, D, Murphy T, Anno PR, Kim YM, and Salama GRA Nitric oxide activates skeletal and cardiac ryanodine receptors. Cell Calcium. 1997;21: 19-29.

32- Eu JP, Xu L, Stamler JS, and Meissner G. Regulation of ryanodine receptors by reactive nitrogen species. Biochem Pharmacol. 1999; 57: 1079-1084.

33- Meszaros LG, Minarovic I, and Zahradnikova A. Inhibition of the skeletal muscle ryanodine receptor calcium release channel by nitric oxide. FEBS Lett. 1996; 380: 49-52.

34- Stoyanovsky D, Murphy T, Anno PR, Kim YM, and Salama G. Nitric oxide activates skeletal and cardiac ryanodine receptors. Cell Calcium. 1997;21: 19-29.

35- Perkins WJ, Han Y-S, and Sieck GC. Skeletal muscle force and actomyosin ATPase activity reduced by nitric oxide donor. $J$ Am Physiol Soc. 1997;1326.

36- Jaffrey SR, Snyder SH. PIN: an associated protein inhibitor of neuronal nitric oxide synthase. Science. 1996; 274: 774-777. 
37- Guo Y, Greenwood T, Petrof J, Hussain SNA. Expression and regulation of protein inhibitor of neuronal nitric oxide synthase in ventilatory muscles. Am J Cell and Mol Biol. 1999; 20:319-326.

38- Schuman EM, Madison DV. Nitric oxide and synaptic function. Annu Rev Neurosci. 1994; 17: 153-183.

39- Lawler JM, Hu Z. Interaction of nitric oxide and reactive oxygen species on rat diaphragm contractility. Acta Physiol Scand. 2000; 169: 229-236.

\section{الملخص العربي}

ان هذه الدراسة تم انجازها لتوضيح تأثثير أكسيد النيتريك على التوصيل العصبي العضلي تحت تأثثر

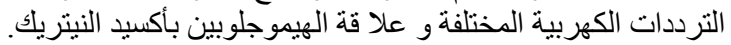

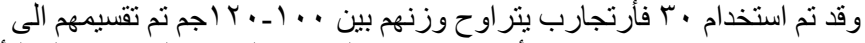

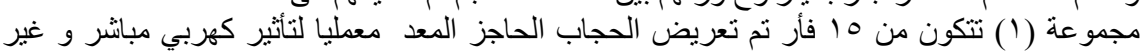

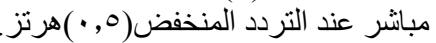

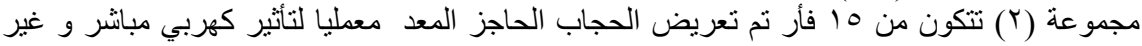

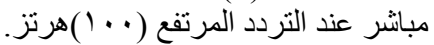

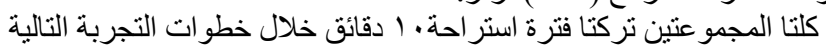

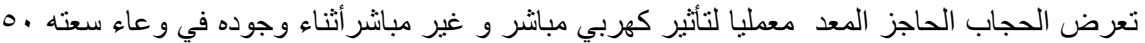

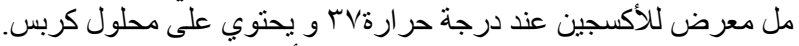

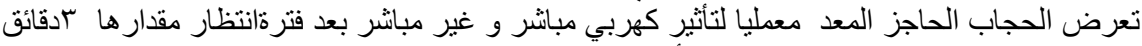

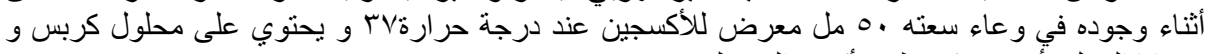
مضافا اليه لـ أرجنين كمعطي لأكسيد النيتريك.

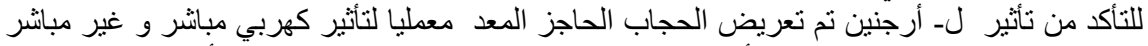

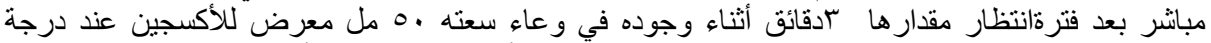

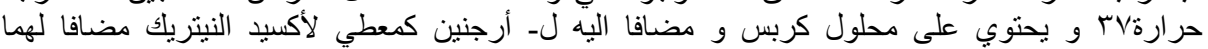

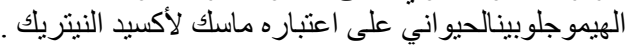

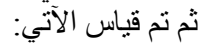

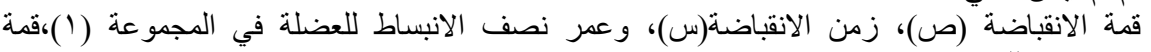

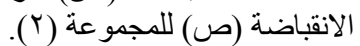
وقد وجد أن أكسيد النيتريك يقلل النقل العصبي العضلي عند تحفز الحجاب الحاجز المعد معطليا لتأثير

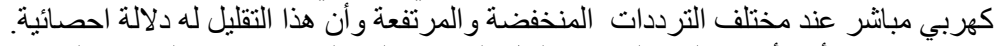

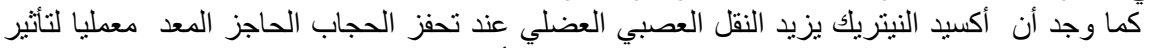

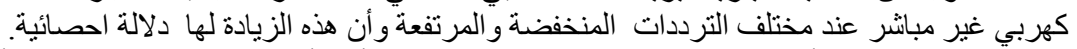

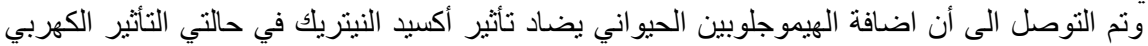
المباشر و غير المباشر و عند الترددات المنخفضة والمبر المرتفعة. الاستنتاج

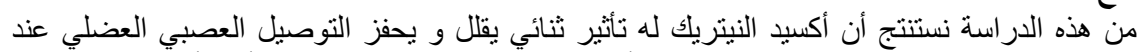

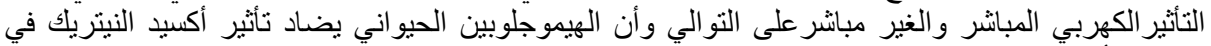

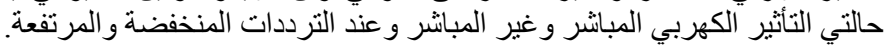

